THE INCOME-TAX AND GRATUITIES TO TEMPORARY LIEUTENANTS, R.A.M.C. To the Editor of THE LANCET.

SIR,-As is well known, certain gratuities and bonuses are granted by the War Office to temporary lieutenants of the Royal Army Medical Corps after 12 months' service, and a question has arisen as to whether such grants become taxable as "income" under the present Finance Acts. As the matter was one which was by no means clear and was of much interest to the military members of our profession, I applied to Sir Henry Craik, M.P., K.C.B., the Parliamentary representative for Aberdeen and Glasgow Universities, for his valuable aid in putting a question to the Treasury through its Parliamentary Secretary, Mr. Montagu. The reply, written and addressed to Sir Henry Craik, is, I take it, of sufficient importance to be recorded in your journal, and I accordingly append it:-

I return herewith the letter from the Medical Defence Union which you handed to me respecting bonuses and gratuities given to temporary lieutenants, R.A.M.C. It seems probable that these bonuses and gratuities are generally given, under the officer's contract, for satisfactory service. At any rate there is no reason to doubt that they are given in respect of and in consideration of his services, and as such they will be liable to income-tax. I may perhaps add that firstly an officer in the Royal Army Medical Corps will come under the liberal relief provisions of Section 25 (1) of the Finance (No. 2) Act, 1915, if his total income does not exceed £300, and secondly, under Section 13 (1) of the Finance Act, 1914 (Session 2), and Section 20 of the Finance Act, 1915, he will only bear tax in respect of the practice he has given up on the basis of the actual profits (if any) of the year, instead of on the average of the past three years.

This will effectively clear the issues involved and make the position no longer doubtful. I am, Sir, yours faithfully,

A. G. BATEMAN,

General Secretary, Medical Defence Union.

4, Trafalgar-square, W.C., Feb. 4th, 1916.

\section{AMMONIA AS AN ENEMA.}

To the Bditor of THE LANChT.

SIR,-May I draw your readers' attention to the effectiveness of an ammonia enema in the treatment of post-operative ileus and intestinal paresis. This sequela of an abdominal operation all have found to be most distressing to the patient, while it is exasperating to the surgeon, and in extreme cases even dangerous to the patient's life. I understand that at the front it has proved frequently a fatal complication of operations for abdominal wounds.

The prescription is liq. ammon. fort. $1 \mathrm{dr}$., water 1 pint, administered as an enema; its effect is greatly enhanced by a hypodermic of pituitrin extract 1 c.c. half an hour previously. This treatment is sure to result in a good motion and discharge of excessive flatus, and again and again $I$ have found it to act where the ordinary enemata, turpentine, eserine, \&c., had failed. Two words of warning I would give-namely, that if used frequently, or if used in greater strength than I suggest, injury to the rectal mucous membrane is liable to take place. On two occasions the daily administration of the enema for three consecutive days resulted in a certain amount of rectal hæmorrbage. On another occasion the mistake of a nurse in putting in too much ammonia gave the patient a very painful septic colitis lasting for a week.

My excuse in writing about this is that although I do not claim originality I have not been able to find in any text-book any mention of ammonia used as an enema, nor have I ever met anyone in England who ever heard of it. Yet I am convinced of its importance.-I am, Sir, yours faithfully,

T. A. BLACK, M.B.,
Feb. 1st, 1916.
Hesident Medical Officer, Barnes Convalescent
Hospital, Cheadle. Hospital, Cheadle.

\section{MATRICULATION AT THE UNIVERSITY OF MANCHESTER.}

To the Editor of THE LANCET.

SIR,-In the report of the Committee of Management to the Conjoint Examining Board of the Royal Colleges, as well as in the report of the Comitia of the Royal College of Physicians, it has been stated that Latin is no longer a compulsory subject in the entrance examination to the Faculty of Medicine in the University of Manchester.

I should be glad if you would allow me to correct this misunderstanding. The University of Manchester has not modified the matriculation requirements.-I am, Sir, yours faithfully,

Feb. 8th, 1916.

G. ELLioT SMITH,

Dean of the Faculty of Medicine, University of Manchester.

** The excerpt from the report of the Committee of Management, in our account of the Comitia of the Ruyal College of Physicians of London, was an accurate reproduction of the words of the report.-ED.L.

\section{THE TREATMENT OF WHOOPING-COUGH. \\ To the Editor of THE LANCET.}

SIR, - I have read with interest the annotation on whooping-cough in THE LANCET of Jan. 29th. I vividly remember the sufferings of my own children several years ago from this horrible disease, and the heart-breaking failure of one drug after another to even more than very slightly relieve the symptoms. Practically every one of those mentioned was tried under the advice of a dis. tinguished colleague. From that time until a year ago I have as signally failed. During the early part of 1915 several cases came under my notice, and I painted the children's chests front and back with a mixture of cantharides, croton oil, and almond oil. The result was most gratifying. Every case was aborted within 14 days. The following is a good formula :-

$$
\begin{aligned}
& \text { R } \quad \text { Ol. croton. } \ldots \begin{array}{llll}
\ldots & \ldots & \ldots & \xi \\
\text { i. }
\end{array} \\
& \begin{array}{lllll}
\text { Cantharadini } & \ldots & \ldots & \mathrm{gr}^{1 .} \\
& \ldots & \ldots & \text { gri. }
\end{array}
\end{aligned}
$$

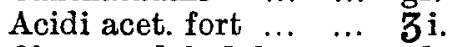

$$
\begin{aligned}
& \text { Ol. amygdal. dulc. } \ldots \text { ad. } \zeta \text { viii. }
\end{aligned}
$$

The painting was carried out weekly and occasioned no distress. I am, Sir, yours faithfully, Bournemouth, Feb. 1st, 1916.

W. J. MIDELTON.

Sodium Gynocardate in Leprosy.-Mr. W. Martindale writes to us, pointing out that palmitic acid is one of the natural constituents of genuine chaulmoogric acid, and cannot be termed "an impurity," to use Sir Leonard Rogers's phrase in our columns last week. Samples may certainly vary in the amount contained.

The South African Hospital. - Lord Gladstone, writing to the press on behalf of the South African Hospital and Comforts Fund, has intimated that a programme has now been drawn up providing for a com. pletely equipped hut hospital in Richmond Park. As far as possible the medical and nursing staff will be obtained from South Africa. The office address of the institution is 3, London Wall Baildings, E.C. 